\title{
Histoire de la Conquête de la Floride in Time - Legitimizing and Framing the Spanish Conquest of Florida
}

Franca König

\section{Introduction}

Travel books have been around for ages and fascinated those who stayed at home with magnificent reports from abroad. The same goes for historic accounts on the conquest of the 'New World'. This chapter deals with Histoire de la Conquete de la Floride which is a 1731 travel account on the Spanish conquest of Florida in the $16^{\text {th }}$ century that is quite unique in its publication history and content. It is this study's interest to read between the lines and find out which motivations really lie behind the publication of the book. What can a book actually reveal that was originally written 65 years after De Soto's conquest by an outsider with a personal interest in the matter; a book that was then translated by a Frenchman after another half century had passed and was finally published by a third man in the Netherlands forty years after the translation, more than hundred years consequent to the original book and almost two hundred years after the actual conquest took place!? This already indicates that Histoire de la conquete de la Floride possibly is not 'just' another travel book. 
This chapter therefore sets out to analyze firstly how the travel account changed throughout time and editions and how the respective publishers framed the original content according to their origin and interest. It secondly investigates how the original author tries to justify and legitimize the Spanish conquest of Florida through but not limited to the presentation of the Native Americans. In order to do so, the first part of the chapter responds to the first research question respectively. It provides an introduction into the content, historic background and setting of the book. Moreover, it elaborates on the original author, the development of his piece of literature in different editions throughout time and the related translator and publisher of the 1731 version of Histoire de la conquete de la Floride. The first section finally categorizes the travel account in terms of validity and in comparison to other analogous literature. The second part, against it, focuses on the content analysis of the 1731 French edition and the original Spanish version. It elaborates on the differences between these versions and the related diverging perceptions of the respective authors and responds to the second research question in assessing the presentation of the conquest and the Native Americans as the 'other'. It furthermore evaluates the presentation of the Spaniards. Finally, the third section of the chapter summarizes the findings in a conclusion. It holds that the travel account has changed tremendously over time, possibly not so much in content, but certainly in the way it was presented and framed by translators and publishers. Other than that, this chapter argues that De la Vega, the original author, does indeed attempt to justify the Spanish conquest, but at the same time glorifies the Native Americans and thus functions as a mestizo mediator between both the American and the Spanish culture.

\section{The Book in Time}

Interestingly, Histoire de la conquête de la Floride is just one of many editions of the Spanish original La Florida del Inca which was published in 1605 , written by the Inca Garcilaso de la Vega. It is essential to understand the French translation, which this chapter analyses, in its time setting and scenery in order to be able to assess the reliability and validity of the book. The content of La conquête de la Floride appears rather brief than extensive at first sight. It is a detailed travel report of De Soto's expedition, the conquest of Florida in particular.

The historic background against which the book was written therefore is the conquest of Florida conducted by General Hernando de Soto between 1539 and 1540. It is worth noting, however, that more or less failed expeditions to Florida had taken place 
previous to De Soto's conquest and to further draw attention to the fact that Spanish imperialism in the Americas began much earlier (Irving, 1851, pp. 34-35). When the Italian Christopher Columbus discovered the American continent in 1492 on a mission for the Catholic Spanish Crown, he had pushed the door open for imperial aspirations of the Spanish monarchs. Interestingly, he only landed on the mainland, present-day Venezuela in particular, in 1498 (Diego-Fernández Sotelo, 1987, p.139). From 1500 onwards, Spanish expeditions and conquest missions followed to the American mainland, starting with the conquest of Venezuela, Colombia and especially Mexico. The Spanish Empire was thus expanded towards Southern America first before turning towards the Northern parts of the continent (ibid., pp. 139-142). Hernando de Soto, who was to conquer Florida, was nonetheless already widely involved in the conquests of Southern America. He was born in Barcarrota, Spain in 1501 and began his military career as a commander at the age of 13, accompanying Pedrarias Dávila to Panama (Irving, 1851, p. 35). From his first contact with the American continent De Soto, whom Irving (1851) calls "a soldier of fortune" (p. 35), appeared to search for fame and wealth. De Soto was soon promoted for his strategic knowledge, military achievements and tactic prudence, but possibly also for his reckless use of force against the natives if deemed necessary (ibid., pp. 35-36). In 1532 he was chosen to accompany and assist Francisco Pizarro in the conquest of Peru and greatly contributed to its final conquest (ibid., pp. 36-37). After having spent 24 years with the conquest in Southern America, most of his life at the time, and having experienced the abundance of gold and wealth to be obtained in the colonies, De Soto returned to Spain in 1537, only to be enticed anew by reports from expeditions to Florida that promised even more riches (ibid., pp. 38-39).

It possibly was perceived as both an opportunity and a challenge to the Spanish imperial spirit to 'naturally' expand the Spanish empire in the Americas, when the Spanish Monarchs shifted their attention to not yet conquered or secured parts in the North of the New World (Irving, 1851, pp. 40-41). De Soto therefore had the blessing of the Spanish Crown, when he set out to his expedition and conquest to Florida in 1538 (ibid., p.41-43). He finally arrived to Bahia Honda, Florida in May 1539, where he landed with 620 men and 223 horses according to Hernández de Biedma (1544, p. 3). In roughly a year's time, De Soto's expedition moved north along the West coast of Florida until he crossed over into present-day Georgia in 1540 to explore the region beyond (ibid., passim). 65 Years later the Inca Garcilaso de la Vega would compose a travel account of De Soto's expedition. 


\section{The Author: Garcilaso de la Vega}

'El Inca' Garcilaso de la Vega was born on April 12, 1539 in Cuzco, Peru as Gómez Suárez de Figueroa, precisely one month before Hernando de Soto landed in Florida for its conquest. De la Vega was the son of the Spanish captain and conquistador Sebastián Garcilaso de la Vega y Vargas and the Inca princess la Palla Isabel Chimpu Occlo. He thus was considered a mestizo and possessed roots in both the Spanish aristocracy and the royal Inca family (Llosa, 2009, p. 160). This unique heritage equipped De la Vega with a dual ethnocultural and bilingual identity from early infancy on. His parents did not marry, as the Spanish crown strictly prohibited intercultural marriages, but lived together and raised their son according to their own cultural background each (Medina, 2008, p.119). De la Vega mainly spent his early infancy with his mother, from whom he learned Quechua and was educated in Inca culture. When he turned eleven in 1550, his father, Sebastián Garcilaso de la Vega y Vargas, abandoned Isabel Chimpu Occlo, his Inca concubine, for a younger Spanish woman and allied the former with one of his officers. From then on, De la Vega lived with his father to receive a formal Spanish education in a variety of disciplines such as Latin, Spanish, rhetoric, Christian doctrines, societal manners and horsemanship and later accompanied him on merchant and business trips outside Cuzco (Mataix, n.d.; Mazzotti, 2009, p. 167).

When De la Vega turned twenty, his father died and left him 4,00o pesos together with the last will to finalize his education in Spain. Consequently De la Vega moved to Montilla next to Córdoba in Spain, where he arrived as a young man in 1562. In the following years he lived under the protection and mentorship of his father's brother, Alonso de Vargas, and his wife, Luisa Ponce de León, and mainly dedicated his time to studying and reading (Mataix, n.d.). Now living in Spain, De la Vega struggled to live up to both identities he had inherited from his parents, as he attempted to simultaneously remain in close contact with the royal Inca family in Peru and integrate into Spanish noble society. Due to his mestizo-background and illegitimate status as his father's son, he was nonetheless subject to exclusion and discrimination. It was in this period that De la Vega discarded his (family) name Gómez Suárez de Figueroa and adopted his father's name with an adaption: El Inca Garcilaso de la Vega (Medina, 2008, pp. 119-121). He had thus officially accepted his dual cultural and ethnic identity and published his first book Los dialogos de amor, a translation from Italian into Spanish, under his new name in 1590. In the dedication of the translation De la Vega even refers to his noble Inca extraction (Chang-Rodríguez, 2006, p. 21). Notwithstanding the success of this translation, he remained very interested in American history due to his dual identity. In this context, it appears to be mainly De la Vega's acquaintance with Gonzalo Silvestre, a soldier who had accompanied Hernando 
de Soto to his conquest of Florida and whom De la Vega had met back in Cuzco, which motivated him to write his account on the conquest (Llosa, 2009, p. 160). In 1591, De la Vega moved to Córdoba where he finished La Florida del Inca (also known as Crónicas de la Florida or La Florida) about the conquest of Florida, which he had begun to compose much earlier already (Hakluyt, [1611] 1851, pp.v \& xxviii). He only published his piece of literature, divided into six books, in 1605 and immediately focused on terminating another project, his famous Comentarios Reales de los Incas (Mazzotti, 2009, pp. 167-168). De la Vega had been planning to write the Royal Commentaries about the Inca culture since 1586, when he studied the work of Spanish historians and found Spanish literature about the Incas to fail to portray a correct picture. Some scholars like Medina (2008) therefore see El Inca De la Vega as "the birthing point in the development of mestizaje discourse(s)" (p. 118), and he is indeed well-known for his contributions to Inca history and culture. De la Vega published the first part of Comentarios Reales de los Incas about the life of the Incas in 1609. The second part, the Historia General del Peru on the Spanish conquest of Peru, was only published in 1617 , one year after De la Vega had died.

\section{A History of Books}

For the analysis of Histoire de la conquête de la Floride it is essential to understand the larger history and setting of the piece of literature, as many different publishers and translators with varying intentions played a part in both. It is already remarkable that El Inca De la Vega published the original version of the book in Spanish and Portuguese in 1605 , roughly 65 years after De Soto's conquest of Florida had actually taken place. He himself had not been part of the mission to Florida, but based his book on the report of mainly one of De Soto's soldiers, Gonzalo Silvestre, whom De la Vega had first met in Cuzco and interviewed again in Spain to collect explicit details for his travel account (De la Vega, 1605, pp.1617). Besides Silvestre, De la Vega used the information from written drafts of two other soldiers, Alonso de Carmona and Juan Coles, who also had been to Florida with De Soto during his conquest and put down their memories around the same time that De la Vega began to write his travel account (De la Vega, 1605, pp.17-19). Although De la Vega claims to attempt an objective and truthful portrayal of De Soto's mission, three facts surrounding the original version, La Florida del Inca, question the validity of this claim. Firstly, the travel account was composed with a considerable time delay, namely 65 years after the actual conquest. This already distorts the extent to which the account captures reality, the rather long-gone past. Secondly, De la Vega based his work on eyewitness reports that were 
collected decades after the actual event. This may distort the degree of truthfulness, as 60 -year-old memories are anything but objective or accurate. Thirdly, De la Vega seemed to have an interest in publishing the book quickly in order to prevent plagiarism and thus possibly did not take extensive time to revise his work (Chang-Rodríguez, 2006, p.150). It is further interesting that he went to Lisbon, Portugal, to publish it with a Flemish publisher, Pedro Crasbeeck also known as Peter van Craesbeck (ibid., pp.152-153). Scholars assume that this was due to the declining significance of Spanish publishers and the existing censorship and complex bureaucratic requirements for publications in Spain at the time (ibid.). Moreover, Crasbeeck was known to be a great businessman with an excellent reputation in the publishing business (ibid.).

While the original Spanish and Portuguese versions were published in 1605, long after the conquest of Florida, an English translation appeared in 1611 shortly after De la Vega's publication (Hakluyt [1611] 1851). Richard Hakluyt translated La Florida del Inca, published it in London and died soon after. He had previously made his name known as one of the most famous "chronicler[s] of English overseas expansion in the reigns of Elizabeth I and James I" (Complete Dictionary of Scientific Biography, 2008, pp. 20-21). In this context, the translation of De la Vega's account on the conquest of Florida seems to be no coincidence. Hakluyt's translation into English was originally titled Virginia richly valued by the description of Florida her next neighbour, and was intended to enliven the colony of Virginia in particular as well as general English colonialism (Soylent Communications, 2012).

Although it had taken the English version merely a few years to appear subsequent to La Florida del Inca, more than half a century passed before De la Vega's travel account was further translated. A French literate and lexicographer, Pierre Richelet, had experienced previous success with the translation of travel accounts and thus translated the book and published it in Paris, France under the title Histoire de la Floride in 1670 (Richelet, 1670). Interestingly, his translation only met with bigger response in 1731, when a foreign publisher reprinted the book. A Dutch publisher, Pieter van der Aa, most famous for his maps and atlases, issued an independent version in Dutch in 1706 (De gedenkwaardige voyagie, 1706, passim). Since the beginning of the century, Van der Aa had turned his interest to travel accounts and supplemented them with historic maps, as such travel reports were quite popular and thus profitable between the seventeenth and eighteenth century (Hoftijzer, 1999, pp.41-42; Cholewka, n.d.). The Dutch version thus appeared in Leyden under the title De gedenkwaardige voyagie van Don Ferdinand de Soto na Florida and was the first version to be equipped with maps and images, manufactured by Van der Aa (De gedenkwaardige voyagie, 1706, passim). It was also Pieter van der Aa who reprinted Richelet's French version soon after the Dutch one was successfully introduced. Resorting to the translation by the then 
deceased Frenchman, Van der Aa issued a second French version of De la Vega's travel report in 1731 which he had complemented with his maps and images from the 1706 Dutch edition (De la Vega, 1731). He also made a slight change to the title and published the newly edited French version under the title Histoire de la conquête de la Floride (ibid.). Notwithstanding the lack of in-depth explanation of the circumstances surrounding the abovementioned editions of De la Vega's La Florida del Inca, this section can conclude that there were varying motives for authors, translators and publishers to issue their respective versions. In this setting and within this inextricably intertwined network of intentions, this chapter sets out to analyze the 1731 French edition, its content and purpose and thus elaborates on the translator and publisher in the next sections.

\section{Introducing the Translator}

(César-)Pierre Richelet was a French advocate, man of letters and translator. He is best known for his sense of sarcasm and black humor, his mordacity and publishing the first monolingual French dictionary, the Dictionnaire française (France, 1995, p.244). All assets make him a highly interesting person for the context of translating De la Vega's Crónicas de la Florida, which will be further elaborated upon. Richelet was born into a Catholic family of advocates in Cheminon, France between 1626 and 1631 (Cholewka, n.d.). The exact date is arguably November 8, 1626 as noted by a baptism entry (Bray, 1986, pp.197199.). It was a time of political and language absolutism in France, where French was on the rise as accepted scholarly and official legal language instead of Latin (Rey, 1994, pp.375376). Richelet's mother, Magdeleine Richelet, died in his infancy and thus left him deserted with his younger brother, Antoine, and father, Jean (Bray, 1986, p.200).

Richelet was sent to attend school in Vitry-le-François at the bourgeois Collège des Pères de la Doctrine, where he learned Latin and soon became the secretary and recording clerk of Nicolas Perrot d'Ablancourt, litterateur and early member of the Académie Française (Cholewka, n.d.). The fact that Richelet consequently received his formation under the auspices of Perrot d'Ablancourt is crucial to his later work, as Perrot d'Ablancourt was a translator himself, but a controversial one. Perrot d'Ablancourt's translation practice was to adapt the language of the literature to the modern language in order to improve the style. Critics have marked his free translations by the expression "les belles infideles", which implies that his work is beautiful but unfaithful to the original piece of literature (France, 1995, p.616). It were a number of translations from Greek and Latin into French which earned Perrot d'Ablancourt the expression 'les belles infidèles' and it were precisely 
these translations that he was working on, when he accepted Richelet as his secretary around 1641 (Cholewka, n.d.). Arguably Perrot d'Ablancourt's translation style influenced Richelet in his own translations later on.

By 1650 Richelet benefited from his experience as escritoire, when he was offered a position as private tutor for the son of the Marquis de Courtivron at Dijon (Bray, 1986, pp.204-207). This in turn enabled him to establish contact with various scholars and writers of the time with whom he entered into frequent correspondence (Cholewka, n.d.). Moreover, this period of Richelet's life firstly and most significantly impacted his literary interest and work, as Richelet further developed his translation and language skills and began to compose prose and poetry. Interestingly, the verses he wrote already show his caustic humor and even caused Richelet to be expulsed from Dijon in 1654 for offending public figures with his writing (ibid.). He returned to Vitry-le-François, where he spent the following years as a professor at his old school and continued to compose literature and many sarcastic literary pieces that mocked and ridiculed people Richelet disliked. His irascible temper and hot-blooded character are equally reflected in the violent end of a romantic episode between Richelet and Louison Garnier, a student. Richelet intended to marry her, but was rejected by Louison's father, because he was neither Protestant nor as rich and high in social class as the Garnier family. Subsequent to heated disputes, Richelet turned violent and was finally sued by the Garniers (ibid.).

Richelet left Vitry and his job at the Collège in 1661 and moved to Paris, where he worked as a judge for a short time (Bray, 1986, pp.214-215\&226-228). He however soon quit this profession in exchange for a career as a writer and grammarian that he financed by teaching French classes, while he started to expand his professional literary network (Cholewka, n.d.). Richelet finally published his first larger pieces and was again noted for the sarcasm and caustic irony in his writing. This eventually led to the divisiveness and enmity of Richelet and his former patron, abbot d'Aubignac (Bray, 1986, pp.218-212). In 1664, Perrot d'Ablancourt died and asked Richelet in his last will to complete his works together with his nephew Nicolas Frémont d'Ablancourt. Consequently, three years later Richelet published his first book, as he had finalized Perrot d'Ablancourt's translation L'Afrique de Marmol, a travel account to Africa by the Spanish writer Luis del Mármol Carvajal (ibid., pp.218\&223). The translation experienced great success and initiated a period of great productivity in which Richelet discovered his full creative potential (Cholewka, n.d.). He translated various works, such as De la Vega's La Florida, which Richelet finalized by 1670. The translation was published in two volumes at the royal court in Paris under the full title Histoire de la Floride ou relation de ce qui s'est passé au voyage de Ferdinand de Soto pour la conqueste de ce pays (Bray, 1986, pp.36\&171). The friendship with Nicolas Frémont 
d'Ablancourt is thought to have equally contributed to this highly productive phase and inspired Richelet to compose and publish the Dictionnaire française in 1680, his most famous piece of literature (Cholewka, n.d.). The overwhelming success of the monolingual French dictionary encouraged Richelet to write and publish even more (ibid.). Until his death on November 23, 1698, Richelet had published ten major pieces of literature (Bray, 1986, p.63).

\section{A Publisher's Point of View: Pieter van der Aa}

The life of Pieter van der Aa can be summarized briefly. Pieter van der Aa was born in Leyden in 1659 as the first child of Boudewijn van der Aa, a German stonecutter, and Annetje Hillebrants Poortemuller, both Lutherans (Hoftijzer, 1999, p.21). At the age of nine, his parents arranged for him to become the apprentice of Daniel van Gaesbeeck, a publisher and book printer. The apprenticeship lasted four years, after which Van der $\mathrm{Aa}$ began his career as a publisher, at the time with the same focus as his former mentor: academic literature in Latin and medical subjects (ibid.). He is thought to have continued working for Van Gaesbeeck or another publisher in Leyden for at least a couple of years before he started an independent business himself (ibid., pp. 21-22). Many details of Pieter van der Aa's life, especially his early career, are uncertain or unknown (ibid., p.23).

However, there is agreement that his career advanced rather quickly at some point. This can be seen, as Van der Aa possessed sufficient money to buy his parents' house from his mother in 1685 , subsequent to his father's death (Hoftijzer, 1999, pp. 21\&23). It can further be seen in the many offices he took on in the Lutheran church of Leyden and in the guild of Leyden book sellers and publishers, where he was named chief and eldest several times, starting in 1692 (ibid., p. 23). His growing influence and success is also reflected by the post he was offered in 1694: personal printer of the Walloon College (ibid.). Van der Aa accepted and from then on exclusively supplied the college and its students of theology with literature. This phase of Van der Aa's career appears to be crucial for his later life and his translations in particular, as the students of the Walloon College were mostly French and Dutch and required according books. When he left the position as personal printer in 1699, Van der Aa had without doubt developed into a successful publisher and businessman. He was wealthy, well-known for his works in the Netherlands and able to support his remaining family financially and regarding accommodation and formation (ibid., pp. 24-25). Van der Aa had moreover continued to focus on academic and scholarly publications, such as his Naauwkeurige Versameling Der Gedenk-waardigste Zee 
en Landreysen Na Oost en West-Indiën in 1706. This book was the result of ten years of research and collection of East and West European travel accounts, according to Van der Aa himself (ibid., p.42). The piece of literature is thus an edited collection of different travel reports that were translated into Dutch and supplemented by Van der Aa with remarks, images and maps. The abovementioned Dutch version of De la Vega's La Florida del Inca can be found in this collection respectively (Hakluyt [1611] 1851, p. vi).

Van der Aa's reputation and professional network finally earned him the posts of personal printer to both the university of Leyden and the city of Leyden in 1715 (Hoftijzer, 1999, p. 25). Still today, he is best known for his atlases with maps and images that he (re-) issued engraved in a quite unique and elegant style, mostly into copper plates (Jennings, n.d.). Following the successful publication of Naauwkeurige Versameling, Van der Aa continued to gather travel accounts or descriptive texts about foreign countries (even within Europe) and published them equipped with his remarks and maps (Hoftijzer, 1999, p. 43). Van der Aa profited considerable from the travel literature he sold and soon extended his readership to French-speaking regions through according translations of the same travel reports into French (ibid.). One of these, and actually one of the last works of Van der Aa before his death in 1733, is Histoire de la conquête de la Floride, a newly edited French version of La Florida del Inca. Van der Aa re-issued the originally translated and published text of César-Pierre Richelet in 1731 in his usual manner of complementing it with maps and pictures. Interestingly, the map inserted in the 1731 French edition is the original Dutch map that was issued as part of the Dutch edition in 1706 (De la Vega, 1731, before p. 1). The caption in the 1731 version was adapted into French, but the Dutch title within the map proves that it was merely transferred from the Dutch to the French version (see Fig. 1).

It is further striking that Van der Aa only briefly mentions Richelet in the foreword (Avertissement) of Histoire de la conquête de la Floride and does not refer to him by his full name, although Richelet is explicitly listed as the translator on the cover of the book (De la Vega, 1731). Richelet is shortly acknowledged and even praised for the purity of his translation and his previous work, the Dictionnaire francçaise in particular (De la Vega, 1731, Avertissement pp. 11-12). Van der Aa thus justifies the correctness of the translation, when he states: "Et si l'on veut faire concevoir quelque chose d'exact, $\&$ de chatié, il suffit de dire que cette version est de lui [Richelet]." (ibid., Avertissement p.11). In other words, if one wants to understand something exactly and in all chastity, it is sufficient to tell them that this (1731) version was translated by Richelet. This is interesting, as Richelet was often associated with the aforementioned 'les belles infidèles', beautiful but unfaithful translations compared to the original pieces. Perchance Van der Aa had intended to counter such criticism with this line. 


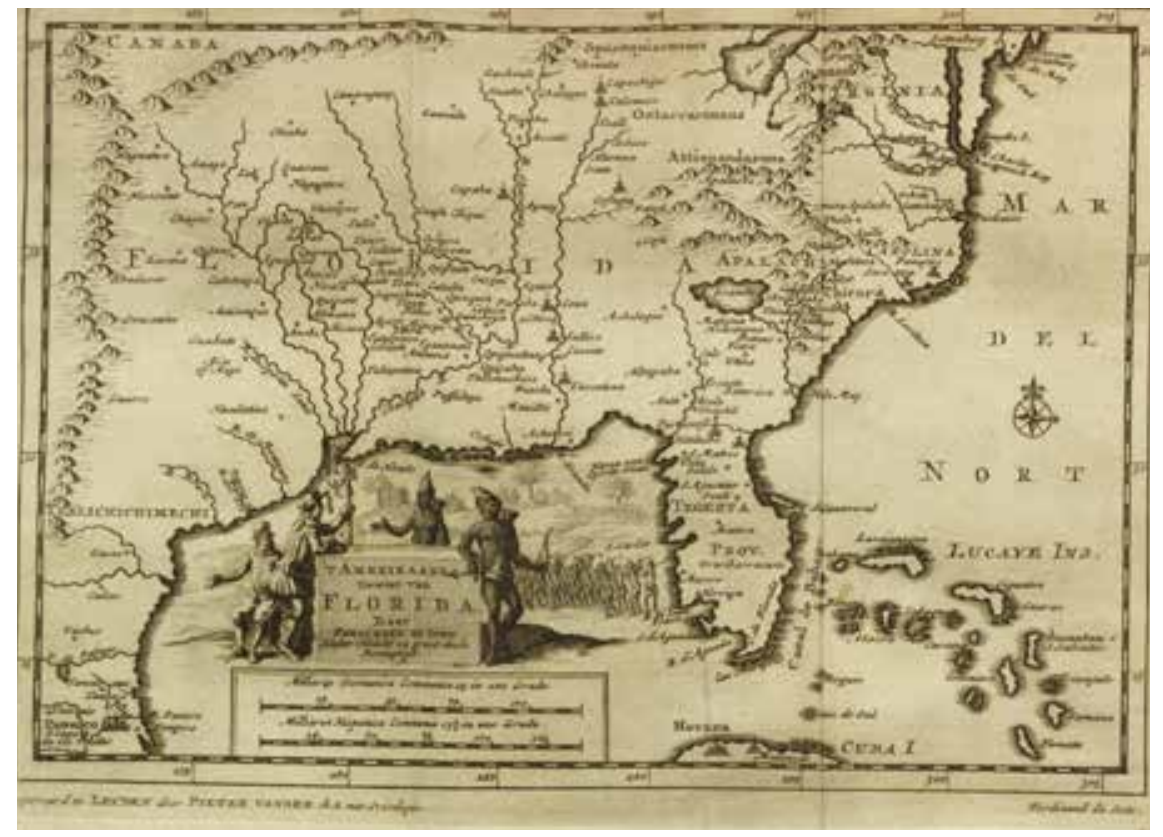

Fig. 1: The American region of Florida, discoverd and largely conquered by Ferdinand de Soto.

Source: [De la Vega] (1731). Histoire de la conquête de la Floride, ou relation de ce qui s'est passé dans la découverte de ce païs par Ferdinand de Soto. Leyden: Pieter van der Aa, before p. 1.

Notwithstanding the accreditation of the work and translation done by Richelet, Van der Aa's focus in the foreword mainly lies on the life of De la Vega and the magnificent travel reports and translations of Jean Baudouin as well as their significance for the Frenchspeaking world. This seems to support the aforementioned impression of high ambition and a good sense of business of Van der Aa. Possibly, he merely gave a brief introduction to Richelet, because he did not want to lessen the value of his own accomplishment, the anew publication of a French version of La Florida del Inca, and thus support his own reputation. Regardless, Van der Aa equally financially throve from this travel account as he had from previous ones and thus died as a wealthy and successful publisher in 1733 . 


\section{Categorization issues: what type of travel literature?}

This chapter has claimed in its introduction that De la Vega's account on the conquest of Florida is not 'just' another travel book. It now attempts to further justify this hypothesis in assessing the nature of La Florida del Inca and locating it in the variety of the diverging branches that exist for such narratives. Travel literature around the seventeenth and eighteenth century was a continuation of the early reports and did not seize to often portray the outland as strange, mysterious and rich in marvels and wonders (Greenblatt, 1991, p. 19). Greenblatt (1991) thus holds that there was considerable false representation of the New World by European voyagers and consequently calls most of the authors of travel accounts throughout the centuries "steady liars" (p. 7). In this context, many scholars contrast De la Vega's La Florida del Inca with the earlier parts of the so-called 'De Soto Chronicles'. The De Soto Chronicles are a two-volumes collection of the most significant accounts on the De Soto travel and conquest of Florida. Apart from De la Vega's contribution, the three remaining authors are Elvas, Rangel and Biedma (Solnick, 1994, pp. 719-720). Their first-hand narratives are often thought to be trustworthy and representative sources, even if there are problems with all of them-including De la Vega's book-as historic documents, as Lankford (2009, passim.) points out.

By contrast, Watson (1995) calls La Florida del Inca "[...]a less reliable source" (p.356). The reasons seem fairly obvious and can be divided into three levels: source, authorship and publication. Firstly, besides the large time span that lies between De Soto's conquest around 1539 and De la Vega's publication in 1605, De la Vega himself was not involved in the event and thus only produced a second-hand narrative. This narrative becomes further questionable as to its trustworthiness, if one takes into consideration that it is based on the reports of eyewitnesses many years after the conquest. Silvestre, De Carmona and Coles had been present at De Soto's mission, but their produced travel memoires (De Carmona; Coles) and interviews with De la Vega 65 years after the conquest (Silvestre) may arguably have been distorted by time and subjective perception. The subjectivity and possible idealization of the truth that derives from the choice of sources thus question the validity of De la Vega's book (Llosa, 2009, p. 161).

Secondly, next to the source-related reasons for challenging De la Vega's credibility, there are reasons regarding De la Vega's authorship itself. Llosa (2009) states: “[...]in his era the borders between history and literature, reality and fiction, were blurry" (p. 161). Like many scholars, Llosa thus indicates that La Florida del Inca rather resembles a mélange between a history book and an adventure novel. The claim that De la Vega's travel account is both based on historical facts and influenced by sixteenth-century chivalric novels is 
often backed up by comparing his narrative to Elvas, Rangel and Biedma, the earlier authors included in the De Soto Chronicles. An example and summary of such a comparison in order to highlight De la Vega's supposed exaggerations and embellishment can be found in Hakluyt ([1611] 1851, pp. xxxiv-xxxv) and is attached to this chapter (see Appendix).

There is, however, another third thought-provoking feature regarding the publication of La Florida del Inca. On the one hand, De la Vega rushed into publishing his travel account due to fear of plagiarism as aforementioned. This may have prevented him from making important changes to his narrative or improving it in its overall quality and thus reliability. On the other hand, De la Vega chose Pedro Crasbeeck as his publisher who may or may not have influenced a more lurid version of the travel report in order to make it appropriate for the masses (which consisted of a limited number of people anyway due to the limited degree of literacy and the high prices of books at the time). Nonetheless, as these are merely assumptions and interpretations, the credibility of De la Vega and his 1605 narrative remains disputed in academic discourse. While certain scholars hold the abovementioned arguments and more against De la Vega, others defend him and point to the foreword in the 1605 version, in which De la Vega explicitly asserts that he merely portrays history in La Florida del Inca and that his intention is far from distorting or idealizing the truth. "Por lo cual, con verdad podré negar que seaficción mía, porque toda mi vida (sacada la buena poesía) fui enemigo deficciones como son libros de caballería y otras semejantes." (De la Vega, 1605, p. 108). De la Vega thus argues that he has always been an enemy of chivalric novels and all writing that claims to be historic but is actually rather fiction than historic documentation.

The controversy surrounding De la Vega and his La Florida del Inca does however not seem to confine itself to the original Spanish version. Derived from the above analysis of the translator and publisher of the 1731 French version, the debate likewise continues for the later editions such as Histoire de la conquête de la Floride. Like many of the translators and publishers, Richelet had previously experienced success with travel accounts before publishing his translation of De la Vega's narrative in 1670. It cannot be stressed enough that travel reports were extremely popular with the readers in the seventeenth century and that profit thus presented an important motive for printers to re-issue La Florida del Inca (Cholewka, n.d.). This does not necessarily lessen the reliability of the follow-up versions and new editions, but it certainly implies that there might be slight alterations to De la Vega's book. Compared to the later versions, it becomes obvious that they are mostly motivated by profit of course, but moreover there seem to be a multitude of colonial intentions such as the translation into English by Hakluyt in 1611. As abovementioned, the English version aimed at encouraging British colonialism, particularly for the colony of 
Virginia. Scholars like Purchas (1991, as cited by Greenblatt) argue that the travel discourse at that time usually accentuated stark contrasts between the outland and the colonial power, and thus highlighted the 'otherness' of the foreigners (pp. 10-11). This alleged supremacy of the Europeans can possibly be found in the later translations of La Florida del Inca, which may also have been meant to thus spur negative integration against the colonies in the respective countries of publication or in Europe as a whole. 'Civilized' Europeans were portrayed against 'barbarous' indigenes in order to make money with the (misre-)presentation of the other and simultaneously support the colonial movement of own country (Purchas, as cited by Greenblatt, 1991, pp. 10-11).

This already makes it rather clear that any translation of De la Vega's narrative cannot be taken as a neutral historic document, but must be categorized carefully as travel literature that may have been framed due to personal motives or distorted in other ways due to the existing mindset of the printer or translator. As Spivak (as cited by Kapoor, 2004, p.644) holds, everyone comes with a certain baggage in terms of their values and judgment, even if they are not always aware of it. It consequently is essential for any analysis of travel accounts to take into consideration that the authors, translators and publishers were impacted in the way they portray events by their environment and the paradigms with which they grew up.

While most unarguably also opted for profit with their publications, De la Vega as a mestizo himself further intended to act as a mediator. This shows in the dedication of his Historia General del Perú amongst others, in which he declares his pride for both his Spanish and his Inca origin and especially emphasizes his compatriotism to all mestizos (Llosa, 2009, p.165). De la Vega's dual identity may have distorted his view on history, especially colonial history such as the conquest of Florida. In particular, De la Vega respectively balances an admiring and praising description of both the Spanish and Native Americans in La Florida del Inca. He thus attempts to present both in a way that highlights their strengths and nobleness as well as De la Vega's own compatriotism for both sides. This original intention to reconcile Europeans and indigenes makes it more difficult to categorize La Florida del Inca amongst all the other travel accounts. It does not seem to be either purely historic or religious, nor does it appear motivated exclusively by lucre. The variety of overlapping motives and intentions to publish and their diverging nature for the original version and the later ones make any analysis and categorization rather complicated. The differences can already be seen when comparing the choice of titles between the editions of La Florida del Inca (see Table 1). 
Table 1: Overview of editions of La Florida del Inca

\begin{tabular}{|c|c|}
\hline Versions & Title \\
\hline De la Vega, 1605 (Spanish) & $\begin{array}{l}\text { La Florida del Inca, } \\
\text { Historia del adelantado Hernando de Soto, Gobernadory } \\
\text { Capitán General del Reino de la Florida, y de otros heroicos } \\
\text { caballeros españoles e indios }\end{array}$ \\
\hline Hakluyt, 1611 (English) & $\begin{array}{l}\text { The worthy and famous historie of the travailes, discovery } \\
\text { and conquest of the great continent of Terra Florida, being } \\
\text { lively paraleld with that of our now inhabited Virginia } \\
\text { Virginia richly valued by the description of the maine land } \\
\text { of Florida her next neighbor }\end{array}$ \\
\hline 1850 & $\begin{array}{l}\text { The Discovery and Conquest of Terra Florida, by Don } \\
\text { Ferdinando de Soto and Six Hundred Spaniards his } \\
\text { Followers }\end{array}$ \\
\hline Richelet, 1670 (French) & $\begin{array}{l}\text { Histoire de la Floride, } \\
\text { ou Relation de ce qui s'est passé au voyage de Ferdinand } \\
\text { de Soto, pour la conqueste de ce pays }\end{array}$ \\
\hline $\begin{array}{l}\text { De gedenkwaardige voyagie, } 1706 \\
\text { (Dutch) }\end{array}$ & $\begin{array}{l}\text { De gedenkwaardige voyagie van Don Ferdinand de Soto } \\
\text { na Florida, } \\
\text { en desselfs ontdekking van de landen in dat gewest, met } \\
\text { al wat aanmerkensswaardig op die vierjarige reyse is } \\
\text { voorgevallen; gedaan anno } 1539 \text { en vervolgens }\end{array}$ \\
\hline $\begin{array}{l}\text { De la Vega, } 1731 \text { (French, based on } \\
\text { Richelet) }\end{array}$ & $\begin{array}{l}\text { Histoire de la conquête de la Floride, } \\
\text { ou relation de ce qui s'est passé dans la découverte de ce } \\
\text { païs par Ferdinand de Soto }\end{array}$ \\
\hline
\end{tabular}

De la Vega's short title emphasizes the Inca focus and his mediating intention can be found in the full title, where he refers to "[...]other heroic Spanish and Native American gentlemen" to stress equality and foreshadow his core message. In the case of the English version, there are even three titles that have appeared throughout time. The earlier titles (1. and 2.) give proof that Hakluyt ([1611] 1850) intended a comparison to Virginia, a British colony at the time. "Virginia richly valued" indicates that the underlying intention may indeed be linked to reevaluate British colonialism. Only in the later version, a re-print by William B. Rye, 'Virginia' was struck out of the title and the focus was shifted to the actual event and Florida itself. Against both these editions, the French version of 1670 carries a rather neutral title that is more descriptive than declamatory or advertising. This is possibly due to Richelet's emphasis on the mere and professional translation, as he 
was a writer and translator himself. By contrast the Dutch edition of De gedenkwaardige voyagie (1706) is titled more pompous. It already promotes the book on the cover through foreshadowing some of the experienced marvels of the journey. Interestingly, the French version published by Van der Aa (1731) does not differ considerably in its title from the original translation by Richelet. It however distinguishes itself slightly, as Van der Aa switched the word 'conquest' from the end of the lengthy full title into the beginning of it, the short title. The French version thus differs from Van der Aa's previous Dutch publication in its simplicity and modest title.

Based on the above analysis, it can be said that La Florida del Inca and the later versions cannot simply be categorized as average travel accounts. While the original narrative was already strongly influenced by the author's personal background and lacks religious motives, the follow-up issues were motivated by a variety of interests and intentions, mostly colonial aspirations and the desire to profit. The degree to which these motives were able to alter or distort the content of De la Vega's travel account has yet to be determined and will be analyzed in the next section through the evaluation of De la Vega's core message in the 1731 French version.

\section{A Matter of Perception?}

It has been said before that De la Vega supposedly pursued two main aims with his La Florida del Inca: firstly, to defend the legitimacy of imposing Spanish rule on the conquered territories of Florida and secondly, to defend the dignity, courage and rationality of the Native Americans in the process. Mazzotti (2009) holds that this dual objective is closely linked to De la Vega's dual identity and intends to build a bridge between indigenes and Europeans (p. 172). He further argues that this is reflected in the language of the author, as both Spanish and Quechua, a native Inca language, were De la Vega's mother tongues. Mazzotti (ibid.) goes on to cite Columbus (2007) who elaborates on the diverging structures of these languages:

"The structure of Quechua[...] sentences differs completely from the structure of sentences in English or in Spanish. Investigators have discovered that indigenous languages lay down different neural pathways in the brain so that, for instance, a native speaking Eskimo can simultaneously see both the duck and the rabbit in the duck/rabbit gestalt, an example of a non-binary perception. That is, where an English or a Spanish speaker is trained to use an either/or distinction that separates items, a native American speaker will use an and/and connection that weaves things together." (Personal Statement) 
In other words, De la Vega possibly had another and/and perception of the Native Americans and the Spanish, while European readers as well as later translators and publishers could only perceive his representation as an either/or distinction. Mazzotti (2009) proves such a stylistic non-binary presentation of the other with examples from De la Vega's Royal Commentaries (p.172). Mazzotti explains De la Vega's dual perspective by what he calls 'Discursive Migration': the integration "from royal indigenous oral narratives to the high rhetoric of sixteenthcentury Spanish historiography" (ibid., p. 176). Obviously, the French translation of La Florida del Inca possibly cannot reflect this specific characteristic of De la Vega's original narrative and moreover may have been framed due to differing intentions. It thus must be compared to the original 1605 Spanish version with particular focus on the representation of the Native Americans, who personify the 'other', and the Spanish conquerors.

Already at first view there is an obvious difference between the French translation and the Spanish original: the chapters are not consistent. De la Vega's La Florida del Inca is divided into eight parts: so-called 'books' (libros) with the numbers one to six, of which books two and five are further divided into first and second parts. Against it, the 1731 French version is already arranged differently in its overall structure. It is divided into a first and second volume, both of which consist of four 'books' (livres). Whereas the first book in the Spanish version consists of fifteen chapters (De la Vega, 1605, Capitulos I-XV), the French livre premier is composed of merely thirteen chapters (De la Vega, 1731, Chapitres I-XIII). Likewise, the Spanish Primera Parte del Libro Segundo is divided into thirty chapters, while the French second book only comprises twenty-eight. The arrangement of the books and number of chapters continues in a similarly inconsistent manner between the two editions.

They do, however, not only differ in their structure. When comparing the chapter arrangement in terms of their content, it becomes clear that Van der Aa (1731) altered the original Spanish narrative beyond the new composition of the various parts. This can be seen especially in the second chapter of the first book in both versions. Besides the footnotes that were added by Van der Aa to elaborate on certain events or criticize historic dates and facts, there are obvious changes in the content arrangement. De la Vega (1605) begins chapter II with a description of the difficulties anyone faces who wishes to describe Florida and its history, and continues with a short description of the discovery of the natural borders of Florida by various Spaniards at various times (pp. 22-23). By contrast, the same chapter in the French version starts with a paragraph on the name Florida and its first discovery, both of which is mentioned only later in the original narrative (De la Vega, 1731, pp. 3-4). Equally, the titles were corrected in the French translation. While De la Vega mixes two subjects in the title for chapter IV, where he mentions both further journeys to Florida and the traditions of the Natives, the French narrative reduced the focus of the 
title to the religion and traditions of the Native Americans in Florida (Religion \& coûtumes des peoples de la Floride). This 'correction' is further reflected in the content. The French version rearranged the first part of the Spanish chapter IV (the paragraphs about further journeys to Florida) and removed them from chapter four only in order to include them in the previous chapter about the travels and conquest missions to Florida (De la Vega, 1605, p. 26; De la Vega, 1731, pp. 9-10).

It therefore appears that the 1731 French version adjusted the Spanish version in its structure and content. Where the Spanish version often is much more loose in structure and style, sometimes even jumps back and forth in time, the edition by Van der Aa rearranged the content in a way that is historically and logically more coherent, but thus distorts the original by De la Vega. This thus confirms the aforementioned hypothesis of Richelet's 'les belles infidèles'-translations, as this arrangement of content and chapters can already be found in the first French edition (Richelet, 1670, passim). Regarding the composition of the translated La Florida del Inca, Richelet restructured and thus distorted De la Vega's narrative. Based on this case, it could hence be argued that Richelet's considerable sense of order and esthetics indeed impacted his translations and that he altered the original book beyond the adaption of the language to modern French. However, there seem to be merely slight changes to the actual content in terms of sentences and expressions. The 1731 French version can consequently be used nonetheless to analyze De la Vega's presentation of the Native Americans and the Spanish conquerors.

\section{Presenting the 'Other': Native Americans}

The Native Americans in Histoire de la conquete de la Floride are portrayed rather negatively despite the earlier assumption that De la Vega intended to express his sympathy to them and thus balance the narrative between indigenes and Spaniards. This can already be seen in one of the first chapters, Chapter IV, which discusses the traditions of the Native Americans of Florida (De la Vega, 1605, pp. 26-29; De la Vega, 1731, pp. 10-14). The French version commences "Les peuples de la Floride sont idolatres, \& tiennent le Soleil \& la Lune pour des Divinitez[...]" (De la Vega, 1731, p. 10). The portrayal of the indigenes as heathens who worship the sun and the moon presents a stark contrast to the predominance of Christianity in sixteenth- and seventeenth-century Europe and thus supports the European perception of the indigenes as the strange 'other'. Paganism was negatively connoted at the time and thus constitutes a disadvantageous trait of the natives.

The chapter goes on to describe the custom of polygamy amongst the indigenes 
in Florida. When it explains the corporal punishment or even death penalty that wives received for being infidel to their husbands, the text clearly judges the Indians as barbarians by calling the punishment cruel (De la Vega, 1731, p. 10). This presentation of the natives nonetheless appears to focus on depicting them as barbarians instead of intentionally evil or malicious. This may possibly serve both a rapprochement between the indigenes and the readers as well as a justification as to why the Spanish had to conquer and 'civilize' Florida and its people. Interestingly, it is this context of polygamy that provides an example of De la Vega's function as a mestizo mediator. Following the part on polygamy amongst the Florida natives, he adds a paragraph about polygamy amongst the Inca in Peru, where it is only allowed for the chiefs and nobles. Here, De la Vega actually defends this custom by explaining that these higher-ranked Inca are those who carry responsibility and wage war and thus must have numerous children in order to support them with their tasks and battles (ibid., pp. 10-11). While these previous characteristics were rather negative, the chapter defends the natives of Florida with regards to the assumption that all indigenes are cannibals. The author states that there was no evidence for this during De Soto's conquest, but that their existence in Florida cannot be excluded either (ibid., p. 12). Nonetheless, this defense is still far from praising the American Indians as noble or equal to the Spanish. Praise can only be found in the next paragraph about the clothes of the indigenes, where it reads: "[...] which [the clothes] they manufacture so well that one could use them like cotton fabric." (ibid.). Similarly, although the natives are depicted as walking around half-naked, the author argues that their women are always fully and modestly dressed (ibid., p. 13). The suggested glorification of the Native Americans continues likewise in both chapters: their strength and skill regarding arms, particularly bow and arrow with which they even outcompete the Spanish (De la Vega, 1605, p. 28; De la Vega, 1731, p. 13).

While Chapter IV conveyed an ambivalent image of the indigenes and does not differ very much across the two versions, other parts of Histoire de la conquête de la Floride present the Native Americans clearly negatively. Chapter I of the second book in the French edition (De la Vega, 1731, pp. 41-44) gives evidence for this in various ways. Firstly, the Indians are mostly called Barbares and thus the reader is reminded that they are different, that they constitute the barbarian 'other' against the civilized Spaniards (ibid., p. 42). Secondly, they are described as savages who fear the Spanish due to earlier encounters with other Spanish conquerors (ibid., pp. 42-43). Thirdly, the indigenes are presented as wild and brutal due to the depiction of their chief who desires to kill the Spanish soldiers. This, however, is not only a negative trait, as it signals superiority of the natives, when the soldiers of De Soto do not dare to leave the ship at first (ibid., pp. 43-44). Only when the chief sends them four of the natives as hostages to guarantee the lives of the Spanish if 
they disembark, the Spaniards dare to send out four of their own soldiers as scouts. It is an equally positive description of the Native Americans' cunningness and skill that they thus convinced the Spanish to leave their ship. Likewise, the chapter continues with the flight of the Indian hostages from the ship who tricked the Spanish in doing so and from then on hold their four scouts as their own hostages (ibid.).

Although there is a slight note of superiority in comparison to the Spanish at times, the indigenes are mostly connoted negatively. The following chapters illustrate this in an obvious manner. Chapter II of the second book narrates a festival of the natives to celebrate the murder of three of the Spanish hostages who are chased and injured by arrows until they die:

[...]les obligeant de courir tour à tour d'une extremité de la place à l'autre, on les tirât de fleches; afin que leur mort fût plus lente, leurs tourmens plus sensibles, \& la réjouissance plus célèbre \& de plus longue durée. (De la Vega, 1731, pp. 44-45)

The text clearly condemns the torture of the Spaniards and even imputes wickedness and a certain enjoyment of violence to the indigenes. The above quote underlines this by stating that the Indians made the death of their hostages as slow as possible and their agony as unbearable as possible and thus relished their misery. The life of the fourth Spaniard, a youngster named Juan Ortiz, is spared consequent to the plea of the chief's wife. He is enslaved instead under tough, almost inhumane conditions (ibid., pp. 45-46). Although this sense of mercy appears a slightly positive trait within all the depiction of cruel and brutal traditions of the indigenes, it soon is turned into a negative feature as well. Ortiz slowly languishes due to the hard work and is to be burnt alive during another festivity arranged by the chief (ibid., p. 46). Here again, the chief and his subalterns are portrayed brutish and cold-blooded, while his wife and daughters who step in once more to save Ortiz from the fire, present a merciful and courageous contrast (ibid.). The ambivalent description of the Native Americans consequently seems to be an inherent part of the narrative. While the overall image is rather negative and contrasts the Indians as a strange 'other' against the Spanish, there are always also positive traits that distinguish certain individuals.

It has to be remarked that the translation of the French version of 1731 often neglects these noble and positive characteristics that De la Vega attributes to the Native Americans. The exemplary synopsis of Chapter XVIII (De la Vega, 1731), which is Chapter XXIII in the Spanish version respectively (De la Vega, 1605), illustrates this omission of certain phrases or sentences by Richelet (see Table 2). It further supports the hypothesis that the content 
of the original narrative was altered in the French translation. The chapter deals with seven Spanish soldiers who go for a ride and encounter a single American Indian with his wife. In contrast to what the Spaniards expected, the Indian does not flee, but attacks the seven horsemen. The latter decide to merely capture the indigene, as they cannot help feeling respect for him. The Indian however fights back so hard that he injures the Spanish and their horses and is thus finally killed by one of the soldiers (De la Vega, 1731, p. 217).

Table 2: Comparison of the French edition of 1731 with the Spanish edition of 1605.

\begin{tabular}{|c|c|}
\hline De la Vega, 1605 , pp. $166-167$ & De la Vega, 1731, pp. 216-217 \\
\hline $\begin{array}{l}\text { Hecho esto, pudiendo haberse ido con la } \\
\text { mujer y escaparse, no quiso, antes volvió } \\
\text { corriendo adonde había dejado su arco y } \\
\text { flechas, y, cobrándolas, salió a recibir a los } \\
\text { castellanos con tanta determinación y tan } \\
\text { buen denuedo como si ellos fueran otro indio } \\
\text { solo como él[1]. } \\
\text { Y de tal manera hizo este acometimiento } \\
\text { que obligó a los españoles a que unos aotros } \\
\text { se dijesen que no lo matasen sino que lo } \\
\text { tomasen vivo, por parecerles cosaindigna } \\
\text { que siete españoles a caballo matasen un } \\
\text { solo indio a pie, y también porque juzgaban } \\
\text { que un ánimo tan gallardo como el infiel } \\
\text { mostraba no merecíaque lo matasen sino } \\
\text { que le hiciesen toda merced y favor[2]. }\end{array}$ & $\begin{array}{l}\text { Après, au lieu de se sauver avec elle [son } \\
\text { femme], il retourne hardiment où il avoit laissé } \\
\text { son arc, \& s'avance contre les Cavaliers avec } \\
\text { autant de resolution, que s'il n'en eut qu'un à } \\
\text { combattre. } \\
\text { Les Espagnols surpris de cette action, \& croiant } \\
\text { qu'il y auroit de la honte à sept homes d'en tuer } \\
\text { un, voulurent seulement le prendre. }\end{array}$ \\
\hline $\begin{array}{l}\text { Yendo todos con esta determinación, } \\
\text { llegaron al indio, que por ser el trecho corto } \\
\text { aún no había podido tirar una flecha, y lo } \\
\text { atropellaron y procuraron rendir sin lo dejar } \\
\text { levantar del suelo encontrándole ya el uno } \\
\text { ya el otro, siempre que se iba a levantar[3], y } \\
\text { todos le daban grita que se rindiese. } \\
\text { El indio cuanta más prisa le daban tanto } \\
\text { más feroz se mostraba y así caído como } \\
\text { andaba, unas veces poniendo la flecha en el } \\
\text { arco y tirándola como le era posible y otras } \\
\text { dando punzadas en las barriga y pospiernas } \\
\text { de los caballos, los hirió todos siete, aunque } \\
\text { de heridas pequeñas porque no le daban } \\
\text { lugar a poderlas dar mayores. Y, escapándose } \\
\text { de entre los pies de ellos, se puso en pie y, } \\
\text { tomando el arco a dos manos, dio con él } \\
\text { un tan fiero palo sobre la frente a Esteban } \\
\text { Pegado, que era el que a recatonazos más le } \\
\text { acosaba, que le hizo reventar la sangre por } \\
\text { cima de las cejas y le corrió por la cara y lo } \\
\text { medio aturdió. }\end{array}$ & $\begin{array}{l}\text { Ils fondent sur lui si promptement, qu'il } \\
\text { n'eut pas le tems de tirer une seule fois; ils le } \\
\text { renversent, le tiennent à terre, lui crient quartier } \\
\text { \& qu'il se rende. } \\
\text { Mais plus ils le pressent, \& plus il fait paroître } \\
\text { de coeur. Car tout abbatu qu'il est, il les blesse } \\
\text { tous aux jambes, \& pique avec ses fléches le } \\
\text { ventre de leurs chevaux. Enfin il s'échape une } \\
\text { fois d'entre leurs pieds, le releve, prend son arc à } \\
\text { deux mains, \& en donne un si rude coup sur le } \\
\text { front de Pegado, que le sang lui en coula le long } \\
\text { du visage, \& en fut tout étourdi. }\end{array}$ \\
\hline
\end{tabular}


El español portugués, viéndole ofendido y tan mal tratado, encendido en ira dijo:"Pesar de tal, ¿será bien que aguardemos a que este indio solo nos mate a todos siete?"[4]

Diciendo esto le dio una lanzada por los pechos que le pasó de la otra parte y lo derribó muerto. Hecha esta hazaña, requirieron sus caballos y los hallaron todos heridos, aunque de heridas pequeñas, y se volvieron al real admirados de la temeridad y esfuerzo del bárbaro[6] y corridos y avergonzados decontar que un indio solo hubiese parado de tal suerte a siete de a caballo.
Ce Cavalier en colere de se voir ainsi traité, pousse son cheval sur le Barbare[5], lui porte quelques coups de lances, l'atrape à la poitrine, \& le renverse mort à ses pieds. Les Espagnols visiterent au même tems leur chevaux, \& trouvant qu'ils etoient tous blessez legerement, ils reprirent le chemin d'Apalaché, honteux qu'un seul home leur eût donné tant de peine.

As can be seen in the direct comparison in table 2, the same chapter in Histoire de la conquête de la Floride limits itself to brief descriptions of the admirable traits of the Indian. While De la Vega extensively emphasizes the courage of the indigene who attacks the Spanish as if they were a single warrior instead of seven, the French version omits this elaboration and confines itself to stating that the Indian attacks with such determination that he does not leave the Spanish a choice, but forces them to fight (see Table 2, [1]). Likewise, the translation of Richelet completely skips a sentence in which De la Vega further highlights the courage of the Indian and states that this trait earned him the respect of the Spaniards among their decision to spare his life (ibid., [2]). Less significant but nonetheless an omission can be found under [3]; the 1731 edition of Van der Aa leaves out the details on the fight and describes it much more briefly, not as epical as De la Vega. The two most essential changes are [4] and [6] (see Table 2). In the original Spanish chapter, before killing the Indian, the Spanish soldier asks "Should we really wait for this Indian to kill all seven of us despite everything?". The threat that derives from the strength and determination of the indigene is consequently underlined, while Richelet's translation merely states that this horseman was furious and thus moved his horse toward the barbarian and killed him with his lance. Here, Richelet omitted an essential part, but moreover added a phrase as well (see Table 2, [5]). De la Vega does not mention the move of the horse toward the Indian. Regardless, the most significant omission of the French translation can be found in the last sentence of the chapter (ibid., [6]). While De la Vega writes that the Spaniards return in silent admiration of the venturesomeness and strength of the indigene, there is no trace of this in the 1731 Van der Aa version. Instead, the French version only focuses on the shame that the Spanish soldiers felt for almost having been overwhelmed by a single man.

This simultaneously illustrates two things: firstly, it confirms that there is implied admiration and sympathy for the indigenes in the original and further exemplifies how 
De la Vega expresses this in a slight glorification of the Native Americans. Secondly, it demonstrates that there is considerable distortion in the French translation, as Richelet purposefully omitted parts, mostly regarding the favorable traits of the indigenes. Such omissions as found in the synopsis in table 2 can be found throughout the entire narrative. The 1731 version of La Florida del Inca is thus framed in a way that was impacted by the author's differing intentions. The focus in Histoire de la conquête de la Floride lies on maintaining a negative image of the indigenes. This is possibly due to profit as the primary motive for both Richelet as the original translator and Van der Aa as the publisher of the 1731 edition, since a sharper contrast between the barbarous Natives and the civilized Europeans made the book more lurid and thus more successful with the readers.

It thus can be concluded that throughout both, the original Spanish and the newly issued French version, the Native Americans are depicted rather negatively and in stark contrast to the Spaniards. The negative traits are however mostly related to their supposed barbarian and pagan nature and thus indirectly justify the Spanish conquest, as the sixteenth- and seventeenth-century European world view did not question the legitimacy and rightfulness of subjecting pagans to 'civilized' and Christian rule. This is further supported by the portrayal of the Spanish as victims in the situations where the Indians temporarily are predominant. Nonetheless, the narrative continuously further highlights positive characteristics of the indigenes, such as their strength and determination. This causes some degree of contrariness or dichotomy in the description of the natives, as they are sometimes portrayed as barbarians and sometimes as Indians and rather neutral or even positive such as equipped with compassion or nobleness. It is striking that these positive descriptions are rarer in the 1731 French version, where the Native Americans are described much more negatively and exclusively malignant due to omissions of De la Vega's praising phrases and parts. Despite the efforts of the original author, the mediation between indigenes and Europeans does not come across clearly in either version.

\section{The Spanish in La Florida: Legitimizing the Spanish Conquest?}

As against the Native Americans, who indeed present a contrasting 'other', the Spanish are mostly portrayed positively and superior. Taking up the same chapters as in the above analysis of the Indians, the arrival of De Soto and his men to Florida depicts the latter as truly civilized (De la Vega, 1731, pp. 41-41). Chapter I of the second book commences with 
the brief description of the flora of Florida and its variety. Here already, the Spanish are set apart from the indigenes, as they are described as able to value and appreciate the rich flora (ibid., p. 41). The contrast becomes very clear in a direct comparison: “[...]Les Indiens qui les [raisins] estiment peu, ne prennent nul soin de les cultiver[...]. Le General [De Soto] reçût ce fruit avec joie, parce qu'il étoit semblable aux raisins d'Espagne[...]." (De la Vega, 1731, p. 41). In the original Spanish version, the favorable description of the Spaniards and the intention to engage the readers' sympathy for the latter is even more obvious. Instead of applying 'Le General' as a representative of the Spanish, De la Vega (1605) writes: "Los nuestros quedaron muy contentos de las buenas muestras[...]" (p. 51). By calling the Spanish 'ours'/'our fellows' and attributing them with the ability to value the features of the country, De la Vega reinforces the contrast to the Indians as well as the negative integration between the reader and De Soto in view of the 'other'.

The same chapter further gives evidence in favor of the aforementioned hypothesis that violent actions or battles of the Spaniards against the Indians are indeed indirectly justified by portraying De Soto and his men as victims. In Chapter I of the second book the chase of the natives is only caused by the previous attack of the latter on the Spanish (De la Vega, 1731, p. 42). While the indigenes are described negatively, as attacking the soldiers forcefully and chasing them back to the sea, the Spaniards are depicted as acting in selfdefense and finally countering the Indian attack (ibid.). More specifically, the soldiers are said to be organized and disciplined, but this again is formulated in contrast to the Native Americans: 'without the disorder of his [the general] soldiers' in contrast to the disorder of the Indians ("[...]sans le desordre de ses soldats[...], ibid.). In the same context, further positive traits are attributed to the Spanish, whose general encourages them and thus brings out the best in them. Likewise, Chapter XVIII of the third book of the French version justifies the murder of a native by presenting the Spanish soldiers as victims (De la Vega, 1731, pp. 215-217). While the seven Spanish horsemen are depicted as innocent and unsuspecting when they go for a ride, they are brutally attacked by an indigene (ibid., pp. 215-216). Even when the Indian assaults them, they are portrayed as men of honor who respect the Indian's courage and thus decide to only capture him (ibid., p. 216). The Indian is killed only after one of the soldiers is gravely injured by the former (ibid., p. 217).

Just like paganism is interpreted negatively regarding the Native Americans, the Spanish are described as Christian, which is evaluated positively. In the case of Juan Ortiz who is enslaved by the indigenes, this is shown in a part of the text where he desires to die, but does not dare to commit suicide out of piousness (De la Vega, 1731, p. 45). The Spanish original does not deviate significantly from the French translation: "[...] si no fuera cristiano tomara por remedio la muerte con sus manos." (De la Vega, 1605, p. 54). This possibly signals 
manners and social norms as traits of the Spanish that are simultaneously presented in stark contrast to an ethically demoralized Indian society where torture and enslavement of men is accepted. The strong focus on Christianity vs. paganism can moreover be seen in the very last chapter of the narrative, which already carries the title 'Christians died in Florida' (Chrêtiens morts dans la Floride, De la Vega, 1731, pp. 554-558). It ends by telling the story of eight Spanish Jesuits who attempt to proselytize the natives and are killed in the process (ibid., pp. 557-558). The original Spanish version ends with a large paragraph on the injustice and cruelty of these murders, requests vengeance in the name of the Catholic Church and in the name of god and praises Catholicism with flowery religious phrases (De la Vega, 1605, pp. 401-402). Against it, the French version omits this extensive part about the Spanish church and the excuse to avenge the killed Jesuits and equally avenge all shed Spanish blood (De la Vega, 1731, pp. 557-558). It does however briefly mention the request for vengeance. This alteration in the French translation has two possible explanations. It could be due to Richelet's relation with religion, as he had already been rejected by the father of his beloved on grounds of being Catholic. This would explain why Richelet was opposed to the extensive flowery part about praising the Catholic Church. Nevertheless, another possible explanation could derive from the background of the Dutch publisher, Van der Aa. The Netherlands had only gained official independence from the Spanish Empire in 1648 and thus resentment prevailed against the Spanish Crown. Van der Aa thus had a possible motive as well to omit this final part of praise regarding the Spanish Catholic Church and Empire, especially and additionally because Van der Aa was Lutheran, not catholic.

Chapter III of the second book in Van der Aa's version (1731) continues the positive attribution of the Spanish. Ortis manages to kill a lion with only one arrow and is thus honored by the Indian village (pp. 48-49). While it appears like a part of an adventurous tale, the achievement, skill and strength of the Spaniard are nonetheless highlighted, once more in contrast to the Indians: “[...]c'est une chose surprenante que de tuer un Lion dans ce païs-là[...]" (ibid., p. 49). In other words, it is surprising to the Native Americans that someone should be able to kill a lion. This again signals Spanish superiority in strength and skill over the Indians. As indicated before, the Spanish however are also sometimes depicted as admiring and respecting the natives for the rare occasions when the latter are attributed positive features. "Les peoples de ces quartiers sont braves \& fiers, toûjours à l'erte, \& toûjours prêts à combattre. On raconte encore ceci de leur courage." (Van der Aa 1731, pp. 222-223). This praise of their courage, bellicosity and fighting spirit is described consequent to a scene in which a Spanish horse dies, merely from one light injury due to an Indian arrow. When the Spaniards find the horse dead, they are surprised and awed. 
Therefore, the Spanish are often also portrayed as not all-knowing, but even a little naïve. Notwithstanding certain positive and temporarily superior descriptions of the Indians, the Spanish are unquestionably characterized superior. This sense of Spanish predominance stretches to all levels: military strength, skill, moral and ethical purity, social development (civilization), and the like.

\section{Conclusion}

This chapter set out to investigate how De la Vega's La Florida del Inca changed throughout time and editions and how the respective publishers framed the original content according to their origin and interest. The assessment of the different versions and their respective titles implies that publishers and translators have indeed been biased by their environment. As Spivak holds, their backgrounds impacted their perception and thus their intentions. This in turn had an impact on the later editions of La Florida del Inca. The original version was often changed contentwise, like omissions or rearrangements of certain parts as can be found in the 1670 French translation of Richelet and the later reissuance by Van der Aa (1731). De la Vega's travel account was further altered by framing it. This can be seen in the English edition of 1611, where the narrative was put into a different setting, the comparison to the British colony of Virginia.

Based on these results and aware of the possible distortion in the 1731 French version, this chapter has furthermore analyzed the portrayal of both the Spanish soldiers of De Soto as the conquerors and the Native Americans as the 'other'. It aimed at identifying how De la Vega used this description for a possible legitimization of the conquest of Florida. The exemplary chapter analysis shows that this is achieved through a contrasting description of both. While the Native Americans are characterized rather negatively, the Spanish are depicted noble and superior. However, the description of the Indians differs slightly between the original and the 1731 version of Van der Aa. In De la Vega's version the indigenes are presented much more dichotomous: both proud, brave and compassionate as well as inferior, aggressive and pagan. This possibly reflects De la Vega's dual identity and his own struggle with uniting his indigenous Inca background with his Spanish roots. Against it, the 1731 edition with the translation by Richelet leaves out various positive parts and focuses on the negative attributes. By contrast, the Spaniards are equally portrayed in both versions with a largely unaltered description in the French version. In this connection, the focus lies on everything that the Indians are not: Christian, civilized, honorable, technologically and morally superior. 
This contrasting characterization of Indians and Spaniards now legitimizes the Spanish conquest indirectly through indicating that the barbarian natives should be subjected to civilization and Christianity. The narrative continuously implies that their 'otherness' justifies Spanish interference and that it even signifies that the Native Americans must be saved and converted to a more appropriate lifestyle. It furthermore possibly excuses the use of force against the indigenes, as the travel account often justifies Spanish attacks by directly linking them to previous assaults by the Indians and thus putting the Spanish into a victim and self-defense position.

Due to the length limitations of this chapter, the analysis has only been exemplary. Further studies regarding the other versions, namely the 1611 English version and the 1706 Dutch one, would be necessary to confirm the distortion across translations and differing backgrounds of authors and publishers. Other than that, a larger-scale comparative analysis of the entire Spanish and French edition could confirm the found results and thus improve the external validity of this study. This analysis has however clearly shown that books cannot always be trusted just because they claim to be objective and historic. It is essential to know more about a piece of literature than just judging it from its cover and content. Sometimes, there is a whole story behind the book and its own story of journeys and historic events.

\section{Bibliography}

Bray, L. (1986). César-Pierre Richelet, 1626-1698: biographie et œuvre lexicographique. Tübingen: Niemeyer.

Chang-Rodriguez, R. (2006). Beyond Books and Borders: Garcilaso de la Vega and La Florida del Inca. Cranbury: Rosemont.

Cholewka, N. (n.d.). Pierre Richelet (Cheminon, entre 1626 et 1631-Paris, 23 novembre 1698). Musée Virtuel des Dictionnaires. Retrieved online on May 19, 2013, from http://www3.u-cergy.fr/ dictionnaires/auteurs/richelet.html\#6

Columbus, C. (2007). Personal Statement. Hobart and William Smith Colleges. Retrieved online on May 21, 2013, from http://campus.hws.edu/academic/popup.asp?id=58

Complete Dictionary of Scientific Biography. (2008). "Hakluyt, Richard". Vol. 6. Detroit: Charles Scribner's Sons [Gale, Cengage Learning]. 
De la Vega, G. (1605). La Florida del Inca; Historia del adelantado Hernando de Soto, Gobernadory Capitán General del Reino de la Florida, y de otros heroicos caballeros españoles e indios, escrita por el Inca Garcilaso de la Vega, capitán de su Majestad, natural de lagran Ciudad del Cozco, cabeza de los reinos y provincias del Perú. Lisbon: Pedro Crasbeeck. Retrieved online on May 19, 2013, from http://www.scribd.com/doc/14659502/Inca-Garcilaso-de-La-Vega-La-FloridaDel-Inca

De la Vega, G. (1731). Histoire de la conquête de la Floride, ou relation de ce qui s'est passé dans la découverte de ce païs par Ferdinand de Soto. Leyden: Pieter van der Aa.

Diego-Fernández Sotelo, R. (1987). Capitulaciones Colombinas (1492-1506). Zamora, Mich.: El Colegio de Michoacán.

France, P. (Ed.) (1995). The New Oxford Companion to Literature in French. Oxford: Clarendon Press.

De gedenkwaardige voyagie van Don Ferdinand de Soto na Florida, en desselfs ontdekking van de landen in dat gewest, met al wat aanmerkensswaardig op die vierjarige reyse is voorgevallen; gedaan anno 1539 en vervolgens (1706). Leyden: Pieter van der Aa.

Greenblatt, S. (1991).Marvelous Possessions. The Wonder of the New World. Chicago: The University of Chicago Press.

Hakluyt, R. ([1611] 1851). The Discovery and Conquest of Terra Florida, by Don Ferdinando de Soto and Six Hundred Spaniards his Followers. Rye, W.B. (editor). London: Richards [Hakluyt Society].

Hernández de Biedma, L. (1544). Relation of the Conquest of Florida: Presented by Luys Hernández de Biedma in the Year 1544 to the King of Spain in Council. Bourne, E.G. (editor) and Smith, B. (translator). Electronic publication (2003): Wisconsin Historical Society; Digital Library and Archives.

Hoftijzer, P.G. (1999). Pieter van der Aa (1659-1733); Leids drukker en boekverkoper. Hilversum: Verloren.

Irving, T. (1851). The Conquest of Florida by Hernando de Soto. New York: George P. Putnam.

Jennings, M. (n.d.) Aa, Pieter van der. Michael Jennings Maphouse. Retrieved online on May 29, 2013, from http://www.maphouse.co.uk/cartographer/aa-pieter-van-der- 
Kapoor, I. (2004). Hyper-self-reflexive development? Spivak on representing the Third World 'Other.' Third World Quarterly, 25(4), 627-647.

Lankford, G.E. (2009). How historical are the De Soto Chronicles? In V.J. Knight Jr. (Ed.) The Search for Mabila: The Decisive Battle between Hernando de Soto and Chief Tascalusa (pp. 31-44). Tuscaloosa: University of Alabama Press.

Llosa, M.V. (2009). El Inca Garcilaso de la Vega. Review: Literature and Arts of the Americas 42(2), 160-166.

Mataix, R. (n.d.). Inca Garcilaso de la Vega: Apunte biobibliográfico. Biblioteca Virtual Miguel de Cervantes - Biblioteca Americana. Retrieved online on April 20, 2013, from http://www. cervantesvirtual.com/bib/bib_autor/incagarcilaso/pcuartonivelc25d.html?conten=autor

Mazzotti, J.A. (2009). Inca Garcilaso: Migrancy and Modernity. Review: Literature and Arts of the Americas 42(2), 167-177.

Medina, N. (2008). The Religious Psychology of "Mestizaje": Gómez Suárez de Figueroa or Garcilaso Inca de la Vega. Pastoral Psychology 57(1/2), 115-124.

Rey, A. (1994). Linguistic Absolutism. In D. Bloch (Ed.). A New History of French literature (pp. 373379). Cambridge, Mass., [etc.]: Harvard University Press.

Richelet, P.C. (1670). Histoire de la Floride, ou Relation de ce qui s'est passé au voyage de Ferdinand de Soto, pour la conqueste de ce pays. Paris: Gervais Clouzier.

Solnick, B.B. (1994). Review of 'The De Soto Chronicles' by Lawrence A. Clayton, Vernon James Knight, and Edward C. Moore. The Hispanic American Historical Review 74(4), 719-720.

Soylent Communications. (2012). Richard Hakluyt. NNDB Tracking the Entire World. Retrieved online on May 19, 2013, from http://www.nndb.com/people/684/00oog6396/

Watson, T.D. (1995). Review of 'The De Soto Chronicles: The Expedition of Hernando de Soto to North America in 1539-1543' by Lawrence A. Clayton, Vernon James Knight, and Edward C. Moore". Louisiana History: The Journal of the Louisiana Historical Association 36(3), 355-357. 


\section{Appendix}

Source: Hakluyt [1611] 1851, pp.xxxiv-xxxv

\begin{tabular}{|c|c|c|c|}
\hline $\begin{array}{c}\text { PLACES } \\
\text { MENTIONED. }\end{array}$ & $\begin{array}{c}\text { GENTLEMAN OF } \\
\text { ELVAS. }\end{array}$ & BREDMA. & $\begin{array}{l}\text { GARCILASBO DE } \\
\text { LA VEGA. }\end{array}$ \\
\hline $\begin{array}{l}\text { Landed in } \\
\text { Florida (Bay } \\
\text { of Espiritu } \\
\text { Santo). }\end{array}$ & $\begin{array}{l}600 \text { men. } \\
213 \text { horses. }\end{array}$ & $\begin{array}{l}620 \text { men. } \\
223 \text { horses. }\end{array}$ & $\begin{array}{l}1000 \text { men. } \\
350 \text { horses. }\end{array}$ \\
\hline$\ldots$ & $\begin{array}{l}\text { John Ortiz came } \\
\text { to meet us with } \\
10 \text { or } 11 \text { princi- } \\
\text { pal Indians. }\end{array}$ & $\begin{array}{l}9 \text { Indians. } \\
\text { (8 or 10, in So- } \\
\text { to's letter to the } \\
\text { municipal autho- } \\
\text { rities at Cuba ; } \\
\text { printed in Ter- } \\
\text { naux - Compans's } \\
\text { Pieces sur la } \\
\text { Floride.) }\end{array}$ & 50 Indians. \\
\hline$\cdots$ & $\begin{array}{l}\text { The Governor } \\
\text { left Calderon at } \\
\text { the port with } 30 \\
\text { horsemen and } 70 \\
\text { footmen. }\end{array}$ & $\begin{array}{l}26 \text { horsemen. } \\
62 \text { foot soldiers. }\end{array}$ & $\begin{array}{l}40 \text { horsemen. } \\
80 \text { foot soldiers. }\end{array}$ \\
\hline Patofa. & $\begin{array}{l}\text { Thecacique gave } \\
\text { the Governor } 700 \\
\text { Indians to bear } \\
\text { burdens. }\end{array}$ & 800 Indians. & $\begin{array}{l}4000 \text {; and } \\
4000 \text { besides as an } \\
8000^{*} \text { (Sescort. } \text { note p.xxxv. }\end{array}$ \\
\hline $\begin{array}{c}\text { PLACES } \\
\text { MENTIONED. }\end{array}$ & $\begin{array}{l}\text { GENTLEMAN OF } \\
\text { ELVAG. }\end{array}$ & BIEDMA. & $\begin{array}{c}\text { GARCILASSO DE } \\
\text { LA VEGA. }\end{array}$ \\
\hline $\begin{array}{c}\text { Mavila } \\
\text { (the battle). }\end{array}$ & $\begin{array}{l}2,500 \text { Indians } \\
\text { killed. } \\
18 \text { Christians } \\
\text { killed. } \\
150 \text { Christians } \\
\text { wounded, with } \\
700 \text { wounds. } \\
12 \text { horses killed. }\end{array}$ & $\begin{array}{l}20 \text { Christians } \\
\text { killed. } \\
250 \text { Christians } \\
\text { wounded : }-660 \\
\text { arrow-shots. }\end{array}$ & $\begin{array}{l}\text { Upwards of } \\
11,000 \text { Indians } \\
\text { killed.* } \\
82 \text { Christians } \\
\text { killed. } \\
1770 \text { Spaniards } \\
\text { wounded. } \\
45 \text { horses killed. }\end{array}$ \\
\hline $\begin{array}{c}\text { Chicaça } \\
\text { (the battle). }\end{array}$ & $\begin{array}{l}11 \text { Christians } \\
\text { killed. } \\
400 \text { hogs burnt. }\end{array}$ & $\begin{array}{l}13 \text { or } 14 \text { Chris- } \\
\text { tians killed. } \\
300 \text { hogs burnt. }\end{array}$ & $\begin{array}{l}40 \text { Spaniards } \\
\text { killed. } \\
\text { Nearly all po- } \\
\text { rished. }\end{array}$ \\
\hline
\end{tabular}


* The following note is from the Hon. Albert Gallatin's valuable "Synopsis of the Indian Tribes" (Archaologia Americana, ii, 106). "If we were to place implicit faith in the accounts given by Gareilaso de la Vega of the number of Indians in various places, we should infer a greater population than was found to exist one hundred and fifty years later. Considering the sources from which he derived his information, the proneness of common soldiers to swell the number of enemies, and the habitual and notorious exaggeration of the Spaniards of his time, we will in that respect give the preference to the more sober statements of the Portuguese narrator, who kills only 2,500 Indians by the fire and sword, at the storming of Mauvila, whilst Garcilaso swells the number to 11,000 . Yet Gareilaso did not intend to impose on his readers, or exceed, according to his knowledge, the bounds of credibility. Born in Peru, he was deceived by an erroneous analogy, and saw nothing extraordinary in the accounts given to him of eight to twelve thousand Indians collected together. In another place, at Cofaqui or Patofa, the last inhabited district before the arrival of the Spaniards at Cofachiqui, the cacique, who was very friendly, gave them, according to Garcilaso, $\mathbf{4 0 0 0}$ warriors to escort them, and 4000 retainers to carry their supplies and clothing. It must be observed that the total amount of their baggage was such, that, on their departure from Anhayea, each soldier carried his supply on his back. On the seventh day of their march through an uninhubited country, the army was arrested by the termination of the path which they had followed thus far. They were then within twelve leagues of the first village in the province of Cofachiqui, and not one of the 8000 Indian allies could point out the proper direction, which at last was discovered by the Spaniards themselves: And the Indian chief assured De Soto that none of his followers had ever been in that place, and that in their wars with the Indians of Cofachiqui, those of Cofaqui had never passed over their own frontiers. Whether any one Indian warrior has ever been found ignorant of the way to an enemy's village, hardly one hundred and fifty miles distant, and through a country offering no particular obstacle, we are able to judge. According to the Portuguese narrator, De Soto had demanded only six hundred Indians; and when he found himself at a loss which way to pursue, he had no other guide but a young Indian they had brought from Appalache, and who confessed that he did not know where he was. "The Indians of Patofa (or Cofaqui) had been sent back as soon as provisions began to be searee', though the poor men showed a great deal of trouble to leave the Christians before they saw them in a good country. The numbers, as stated in the Portuguese relation, are not in the whole inconsistent with a population nearly the same as at this time. The greatest apparent 


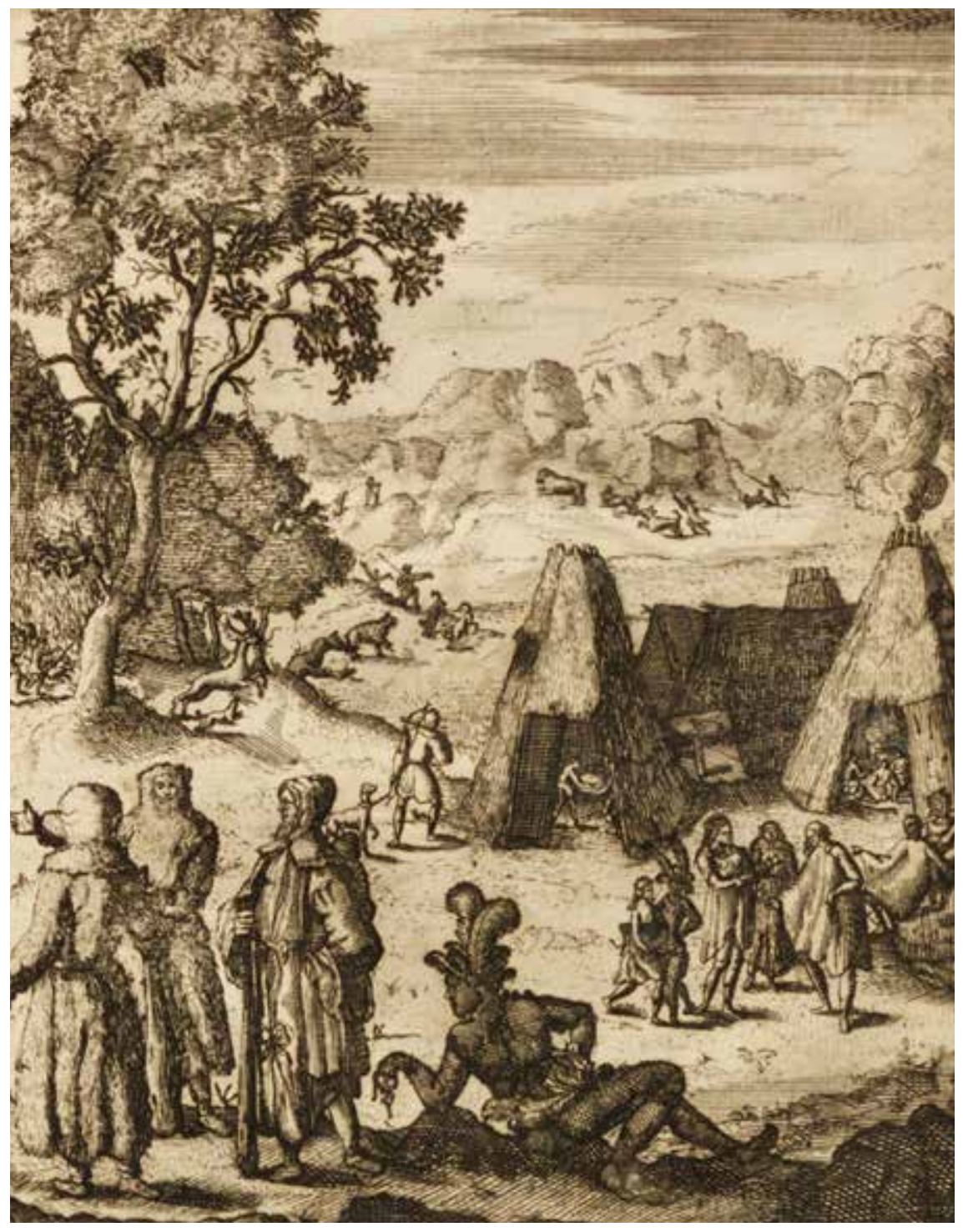

The dress of the savages

Source: Hennepin, L. (1688), Beschryving van Louisiana, nieuwelijks ontdekt ten zuid-westen van NieuwVrankryk. Amsterdam: Jan ten Hoorn, pp. 130-131. 